\title{
Bioethanol Production from Waste Crops and Crop Residues
}

\author{
A. Riungu ${ }^{1}$, A. M. Salim*1, J. Njenga ${ }^{1}$, A.O. Yusuf ${ }^{2}$ and \\ Walyambillah Waudo ${ }^{1}$ \\ ${ }^{I}$ Department of Chemistry, Jomo Kenyatta University of Agriculture and Technology (JKUAT), P. O Box 62000 \\ - 0200 CITY SQUARE, Nairobi, Kenya \\ ${ }^{2}$ Department of Chemistry, University of Nairobi, P.O Box 30197 - 00100 Nairobi, Kenya
}

\begin{abstract}
Rice straws and Husks were converted to reducing sugars by hydrolysis using concentrated sulphuric acid followed by fermentation using bakers yeast. After fractional distillation and purification, $52 \mathrm{ml}(87 \%)$ of ethanol was obtained from $480 \mathrm{~cm}^{3}$ of biomass which was blended with gasoline using different ratios. Physical constants of the bio-ethanol (density and distillation) conformed to Kenya Bureau of Standards specifications. The conclusion is that the bioconversion offers a cheap and safe method of disposing the agricultural residues and conversion of lignocellulosic wastes into ethanol.
\end{abstract}

Keywords: Bio-ethanol, wasted crops, crop residues

\section{Introduction}

Interest in biofuels has greatly increased in recent years. This has resulted from the diminishing reserves of crude oil and the simultaneous increasing demand for mineral oil as well as the environmental problems linked with burning fossil fuels. Bioethanol is mixed with gasoline in various ratios in order to reduce both the demand for gasoline and environmental pollution.

Pure ethanol $\left(\mathrm{CH}_{3} \mathrm{CH}_{2} \mathrm{OH}\right)$ is a clear, colorless liquid with characteristic but weak odour and a strong, burning taste ${ }^{[1]}$. It is a straight-chain alcohol with various uses, e.g. it is used extensively as a solvent in the manufacture of varnishes and perfumes, it is also used as a preservative for biological specimens, in the preparation of essences and flavorings, in many medicines and drugs; as a disinfectant and in tinctures (e.g., tincture of iodine); and as a fuel and gasoline additive ${ }^{[2]}$. The properties of ethanol stem primarily from the presence of its hydroxyl group and the short carbon chain. Hydrogen bonding makes pure ethanol hygroscopic to the extent that it readily absorbs water from the air. It is a versatile solvent, miscible in all proportions with water and many organic solvents. It is also miscible with light aliphatic hydrocarbons such as pentane and hexane as well as aliphatic chlorides such as trichloroethane and tetrachloroethylene.

Bio-ethanol (ethyl alcohol) is an alcohol made by fermenting and distilling simple sugars from plants (biomass). It is a clear colorless liquid, biodegradable, low in toxicity and causes little environmental pollution. Biomass wastes contain a cellulose complex mixture of carbohydrate polymers from the plant cell walls known as cellulose and hemicellulose. These are broken down (hydrolyzed) by enzymes or dilute acids into sucrose that is then fermented into ethanol. Conversion of sugars to alcohol and $\mathrm{CO}_{2}$ takes three to five days, depending on the temperature of the mixture and the type of yeast used ${ }^{[3]}$. There are different grades of bio-ethanol depending on its usage: food grade, analytical grade and fuel grade.

In this study special interest was focused on the fuel grade commonly known as fuel ethanol (85-95\% pure). It is a much cleaner fuel than gasoline and has the following benefits ${ }^{[4]}$ :

- provides high octane, low flame temperature, greater gas volume change,

high specific energy and high heat of vaporization hence achieving higher

efficiency use in optimized engines than gasoline.

- It is low in toxicity, volatility and photochemical reactivity resulting in reduced ozone formation and smog compared to conventional fuels.

- It has high oxygen content which reduces exhaust emissions of carbon monoxide and unburned hydrocarbons.

- It is biodegradable without harmful effects on the environment

There are three types of ethanol feed stocks namely grain ethanol, sugar ethanol and cellulosic ethanol. So far ethanol has been produced mainly from corn and sugarcane. Corn is produced in greater quantity each year than any other grain around the world. It utilizes C-4 carbon fixation, as opposed to the C-3 carbon fixation process used by plants like soybeans and smaller grains. Corn is a more effective carbon source. Refined white sugar is the ultimate product of sugar cane, and this sugar is $99 \%$ pure sucrose which can be converted to ethanol via fermentation. 
In this study cellulosic ethanol was produced from crop residues, specifically rice husk and rice straws. Rice husk is the most abundant agricultural residue in the world. In 1982, seventy million tons of rice husk were produced in Kenya ${ }^{[5]}$. Currently, the annual rice production is estimated at about 52,000 MT from approximately 12,000 hectares of irrigated rice ${ }^{[6,7,8]}$. Therefore, an almost similar quantity of rice husk would be obtained annually. The disposal of the rice husks and straws has been a problem. The current study is an attempt to give a solution to the management of these wastes and at the same time produce an alternative energy source.

Although there are several ways to increase the digestibility of cellulose before it is exposed to enzyme or microbial conversion i.e. acid hydrolysis, enzymatic hydrolysis, and thermo-chemical ${ }^{[9]}$ methods, the current study has used concentrated acid hydrolysis method developed at Purdue University ${ }^{[10]}$ and at Tennessee Valley Authority (TVA) $)^{[1]}$ as it has several advantages including; its simplicity and high sugar recovery efficiency, ability to ferment $\mathrm{C} 6$ sugars efficiently with conventional microbes and it is able to digest silica in biomass feedstock.

\section{Sample collection}

\section{Methodology}

The rice straw and husk (biomass wastes) were collected from various mills in Mwea area situated in the Eastern Province of Kenya in January 2008.

\section{Sample preparation}

Five kilograms of the biomass waste was air dried on the laboratory bench for 3 weeks.

$900 \mathrm{~g}$ of the dried biomass was ground in order to increase the biomass surface area prior to pretreatment.

\section{Determination Of Moisture And Volatile Matter Content}

$5.005 \mathrm{~g}$ of rice straw and $5.002 \mathrm{~g}$ of rice husk were separately weighed using the analytical balance and put separately into two dry beakers. The biomass was dried to constant mass in an air-oven at a temperature of $106^{\circ} \mathrm{C}$. It was cooled in a desiccators and weighed again after one hour; the desiccant used was anhydrous calcium chloride.

Constant mass was considered attained when successive heating for one hour period showed a difference of not more than $5 \mathrm{mg}$ in the net loss in mass.

\section{Calculation:}

Moisture and volatile matter content (at $106^{\circ} \mathrm{C}$ ) was calculated using the following equation

Moisture and volatile matter $=\frac{\left(m_{o}-m_{1}\right) \times 100}{m_{o}}$

Where:

$$
\begin{aligned}
& m_{o}=\text { mass in } \mathrm{g} \text { of the material taken for test } \\
& m_{1}=\text { mass in } \mathrm{g} \text { of the material upon drying }
\end{aligned}
$$

IV. Concentrated Acid Hydrolysis Process.

The Concentrated acid hydrolysis process used in the preparation of ethanol is summarized in Figure 2.

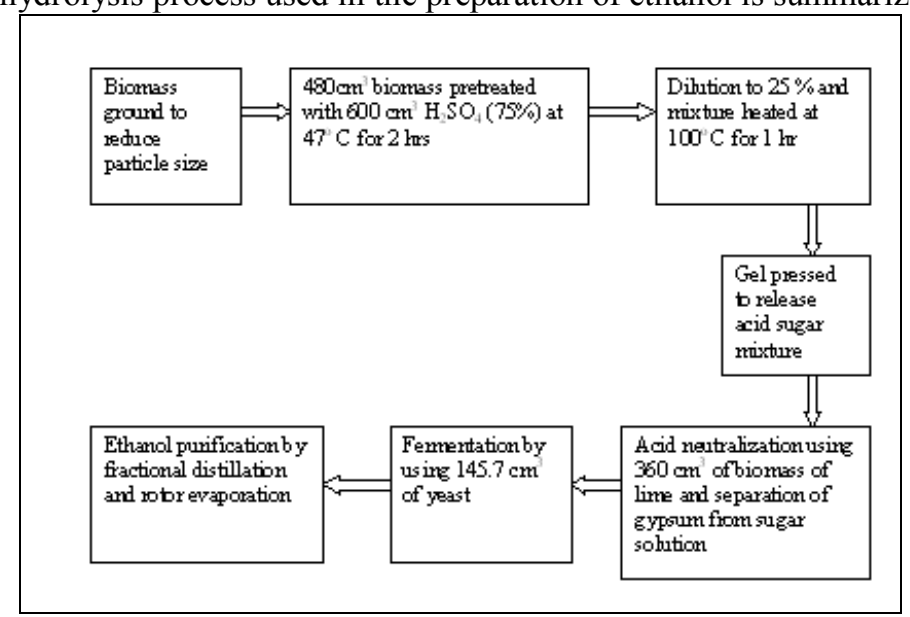

Figure 2: A schematic diagram of the acid hydrolysis process 


\section{Test for sugar}

Benedict's reagent was used to test for sugars. It was prepared by adding $0.865 \mathrm{~g}$ copper (II) sulfate $\left(\mathrm{CuSO}_{4}\right), 8.65 \mathrm{~g}$ sodium citrate $\left(\mathrm{NaH}_{2}\left(\mathrm{C}_{3} \mathrm{H}_{5} \mathrm{O}(\mathrm{COO})_{3}\right)\right)$ and $5 \mathrm{~g}$ sodium carbonate $\left(\mathrm{Na}_{2} \mathrm{CO}_{3}\right)$ in $50 \mathrm{ml}$ distilled water. $1 \mathrm{ml}$ of the sugar solution was added to $3 \mathrm{ml}$ of benedict's solution and placed in a boiling water bath for 10 minutes.

\section{pH determination}

The $\mathrm{pH}$ meter Jenway type 3071(CE UK) was used to determine the $\mathrm{pH}$. The acid-sugar mixture $\mathrm{pH}$ was adjusted from the original $\mathrm{pH}$ of 1.46 to $\mathrm{pH} 3.94$ using $360 \mathrm{~cm}^{3}$ of lime prior to fermentation. The $\mathrm{pH}$ was raised because the ideal $\mathrm{pH}$ for yeast (Saccharomyces cerevisiae) is around 4 to $5^{[3]}$.

\section{Fermentation process.}

$420 \mathrm{~cm}^{3}$ of warm water $\left(26^{\circ} \mathrm{C}\right)$ was added to $145.7 \mathrm{~g}$ of baker's yeast and thoroughly mixed. The yeast syrup was then added to the sugar solution. The apparatus used were four suction conical flasks which were fitted with pipes. The flasks were corked to keep them airtight to maximize production of ethanol and lessen amount of $\mathrm{CO}_{2}$ produced, The flasks were placed on the bench and the setup left for 5 days. The experimental fermentation temperature varied between $23-29^{\circ} \mathrm{C}$, the tabulated optimum temperature for the fermentation process is between $21-30^{\circ} \mathrm{C}^{[3]}$. An indicator that the fermentation was complete was the cessation of bubbling and the sinking of the yeast cake to the bottom.

\section{Fractional distillation process}

The decanted solution from the mash was poured in a $250 \mathrm{ml}$ round bottomed flask placed in a mantle. A fractionating column was connected to the flask. Absolute ethanol was found to have a boiling point of $74^{\circ} \mathrm{C}$ $(770 \mathrm{~mm} \mathrm{Hg}$ ) at the workstation (Juja), Central Province of Kenya. The boiling point of absolute ethanol at standard pressure is $78.3^{\circ} \mathrm{C}^{[1]}$. The heating mantle temperature was set at $75^{\circ} \mathrm{C}$ for the fractional distillation of ethanol from the mash. Since ethanol-water azeotrope $(95 \%)$ has a lower boiling point compared to that of water, the azeotrope turned into the vapour state before water, it condensed and was successfully separated. The diluted ethanol from fermentation obtained was $(510 \mathrm{ml})$ and after distillation using the rotary evaporator the volume yield was $52 \mathrm{ml}$.

\section{Determination of alcohol percentage}

Using distilled water and absolute ethanol (99.8\% ethanol analytical reagent), a series of standard ethanol/water mixtures having an ethanol content of $20 \%, 40 \%, 60 \%, 80 \%$ and $99.8 \%$ were prepared. The refractive index $\left(n_{D}^{26}\right)$ of each of the solution was determined using a refractometer (RFM-310). The refractive index of the sample was determined using the same refractometer.

\section{Preparation of Blends}

E5 was achieved by blending $5 \mathrm{ml}$ ethanol with $95 \mathrm{ml}$ unleaded gasoline while E10 by blending $10 \mathrm{ml}$ ethanol with $90 \mathrm{ml}$ unleaded gasoline to produce the final fuel-grade ethanol product. The blends were light green in appearance because gasoline (regular) is green and ethanol is colourless. The unleaded regular gasoline was obtained from a filling station (Jet petrol station) in Juja, Central Province of Kenya. Analysis were done on the fuel-grade ethanol and compared with Kenya Bureau of standards motor petrol (motor gasoline or motor spirit) specifications.

\section{Final boiling point determination of the blends}

The final boiling point of the blends was determined using an automatic atmospheric machine. $100 \mathrm{ml}$ of the sample was placed in a distillation flask and heated. Initial boiling point is the thermometer reading that is observed at the instant the first drop of condensate falls from the lower end of the condenser tube ${ }^{[12]}$. Immediately after observing the initial boiling point, the graduated cylinder was moved so that the tip of the condenser touched its inner wall. The heating was regulated such that the rate of condensation into the graduated cylinder was uniform. Final boiling point is the maximum thermometer reading obtained during the test ${ }^{[12]}$.

\section{Specific Gravity and Density determination}

Specific Gravity and Density were measured at $20{ }^{\circ} \mathrm{C}$ using an automatic density meter (DMA 4500). The measuring cell was cleaned and air dried on the bench. The measuring cell was filled with each sample independently and it was ensured that there were no air bubbles. 


\section{Results And Discussion}

The moisture content and volatile matter of the husk was $6.85 \%$ while that of straw was $8.29 \%$. Both these quantities agree well with required amounts to make the biomass consistent with the acid concentration requirements for de-crystallization which should be less than $10 \%$.

Benedict test indicated the presence of reducing sugars in small quantities by formation of a green precipitate.

\section{Refractive Index}

The values obtained for refractive Indices of ethanol standards and Sample are given in Table 1. The refractive index of the distillate was 1.3607 (Table 1).

Table1: Refractive Index of ethanol standards and Sample

\begin{tabular}{|c|c|c|}
\hline Percentage (\%) Ethanol & Temperature $\left({ }^{\circ} \mathrm{C}\right)$ & Average Refractive index \\
\hline $\mathbf{2 0}$ & $\mathbf{2 6}$ & $\mathbf{1 . 3 4 0 0} \pm 0.0231$ \\
\hline 40 & 26.1 & $\mathbf{1 . 3 5 0 8} \pm 0.0112$ \\
\hline 60 & 26.3 & $1.3578 \pm 0.0090$ \\
\hline 80 & 26.3 & $1.3606 \pm 0.0069$ \\
\hline 99.8 & 26.2 & $1.3610 \pm 0.0069$ \\
\hline Sample & 26.4 & $1.3607 \pm 0.0069$ \\
\hline Blank & $\mathbf{2 5 . 8}$ & $\mathbf{1 . 3 3 1 2} \pm 0.0069$ \\
\hline & & \\
\hline
\end{tabular}

A calibration curve of refractive index against \% alcohol was constructed (Figure 2) and used to determine the $\%$ alcohol in the original sample.

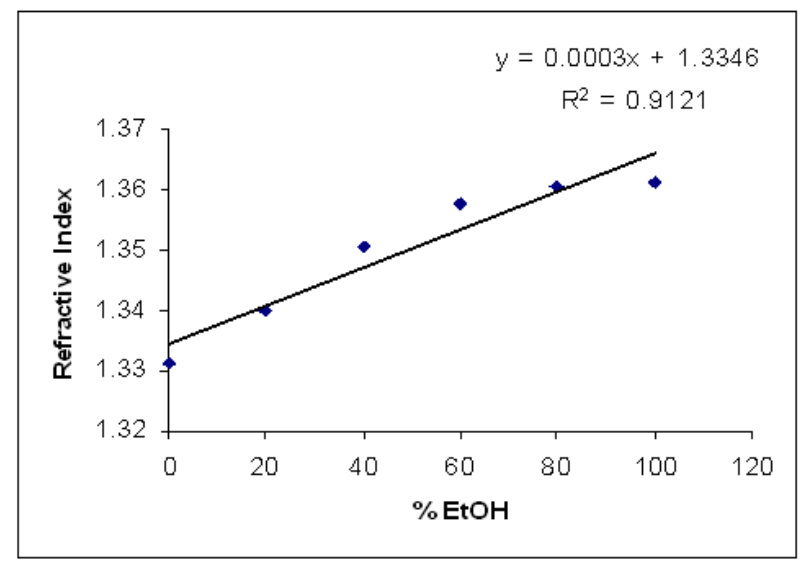

Figure 2. Ethanol calibration curve.

From the calibration curve (Figure 3), the ethanol concentration of the distillate was found to be $87 \%$. Since ethanol is azeotropic in nature, if a 50/50 mixture of ethanol and water is distilled once, the distillate will be $80 \%$ ethanol and $20 \%$ water. No further distillations will ever result in a distillate that exceeds the azeotropic ratio. An azeotrope is a mixture of two or more pure compounds (chemicals) in such a ratio that its composition cannot be changed by simple distillation ${ }^{[1]}$. The quantity of ethanol obtained could also be attributed to the low reducing sugars quantity and variation of fermentation temperature.

Density and specific gravity of the blends

The densities of both E5 and E10 blends and their specific gravity are given in Table 3

Table 2: Density and Specific gravity values of E5 and E10 at $20^{\circ} \mathrm{C}$.

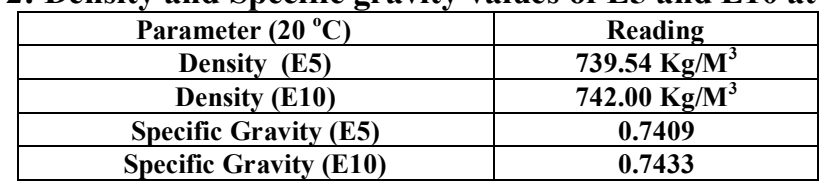


In Kenya, gasoline specifications are stated in the Kenya Bureau of Standards (KEBS) as Kenya Standard KS 275.2:2003, Motor Petrol (motor gasoline or motor spirit)-specification, Part 2: Unleaded motor petrol ${ }^{[12]}$. The KS $275.2: 2003$ standard density has a maximum value of $780 \mathrm{Kg} / \mathrm{M}^{3}$ at $20^{\circ} \mathrm{C}$. The density of hydrocarbons is a strong function of temperature. Fluctuations in gasoline temperature cause gasoline density changes. The density of gasoline $\left(\mathrm{C}_{8} \mathrm{H}_{18}\right)$ is $694 \mathrm{Kg} / \mathrm{M}^{3}$ at $27^{\circ} \mathrm{C}$; that of $\mathrm{E} 5$ and $\mathrm{E} 10$ at $20^{\circ} \mathrm{C}$ was found to be $739.54 \mathrm{Kg} / \mathrm{M}^{3}$ and $742 \mathrm{Kg} / \mathrm{M}^{3}$ respectively. From these results the density of the blends obtained in this study E5 and E10 can be said to conform to KEBS.

\section{Specific Gravity}

The Specific Gravity of E5 and E10 are indicated in Table 2, the specific gravity of gasoline at $20^{\circ} \mathrm{C}$ is 0.739. Gasohol, like many alternative fuels, has a higher specific gravity than standard fuels. This is due to the increase in molecular weight with introduction of the hydroxyl group. The gasohol produced in the current study had specific gravity of 0.7409 (E5) and 0.7433 (E10) at $20^{\circ} \mathrm{C}$.

\section{Distillation range}

The Distillation range of KS 275.2:2003 motor gasoline or motor spirit and those of the prepared gasoline are given in Table3. Observation in Table 3 indicate that the blends conformed to the Kenya standards distillation range because the Final boiling point (FBP) of $182.7^{\circ} \mathrm{C}$ was less than the set maximum limit of 210 ${ }^{0} \mathrm{C}$. This means that the gasohol prepared from the rice husks and straws is within suitable volatile performance.

Table 3.0: Distillation range of KS 275.2:2003 (motor gasoline or motor spirit) and gasohol

\begin{tabular}{|c|c|c|}
\hline \% Evaporated & motor gasoline or motor spirit & Gasohol \\
\hline & Temp $\left.\mathbf{~}^{\mathbf{0}} \mathbf{C}\right)$ & Temp $\left.\mathbf{~}^{\mathbf{0}} \mathbf{C}\right)$ \\
\hline Initial boiling point (IBP) & & 38.8 \\
\hline 10 & 71 & 50.6 \\
\hline 50 & & 1.7 \\
\hline 90 & & 146.5 \\
\hline Final boiling point(FBP) & Maximum 210 & 182.7 \\
\hline
\end{tabular}

\section{Conclusion}

From the findings of this study, it can be concluded that ethanol could be produced from non-food lignocellulosic waste. The obtained ethanol could be blended with gasoline at different ratios. The obtained gasohol (E5 and E10) conformed to Kenya Bureau of Standards specifications (density and distillation range). This would have a major impact on the living standards and economic development in Kenya hence provide additional income to communities. In addition, production of cleaner, more eco-friendly, competitively prized gasohol for both domestic use and export. The estimated cost of a litre of ethanol would be KSh. 50 but by investing in systems which would reconcetrate the sulphuric acid and yeast, the cost would go as low as KSh. 21 per litre of ethanol.

Based on the above conclusions, this study makes the following recommendations:

> More research on the cellulosic content of various non-foods lignocellulosic wastes

> A study on yeast strains which can metabolize five-carbon sugars because Saccharomyces cerevisiae cannot metabolize xylose and other pentoses into ethanol

$>$ Public awareness on the effectiveness of ethanol as a potential gasoline substitute.

\section{Acknowledgements \\ For authors would like to acknowledge their supports.}

\section{References}

[1]. Norman, G, Rene, G and Marcus, G (1989). Drinking and Causalities: Accidents, Poisonings and Violence in an International Perspective pg 156. Routledge, New York.

[2]. The Columbia Encyclopedia, 2007: Ethanol. Sixth Edition, pg 16164. Columbia University Press, New York.

[3]. Catchpole, A. G, Anderson, R. M, Webb, D. F. (1969). Organic Chemistry : A Modern Introduction, pp 191 - 193. George G. Harrap \& Co. Ltd, London.

[4]. Wyman, C (1996). Handbook on Bioethanol: Production and Utilization, pp $1-9$. Taylor \& Francis, Oxfordhire

[5]. Ong'or, D. (1996). Energy from rice husk gasification potentials in rural Kenya pp 15-16

[6]. Government of Kenya 2002. Kenya Rural Development Strategy 2002-2017

[7]. Government of Kenya, 2002. National Development Plan 2002-2008. Effective management for sustainable economic growth and poverty reduction

[8]. Ministry of Agriculture and Ministry of Livestock and Fisheries Development. 2004. Strategy for Revitalization of Agriculture (SRA) 2004-2014

[9]. Badger, P.C. 2002. Ethanol from cellulose: A general review, pp 17-21. ASHS Press, Alexandria, Virginia 
[10]. Tsao, G.T. (1982), "Production of Ethanol and Chemicals from Cellulosic Materials." Process Biochemistry, pp 34-38

[11]. Broder, J.D.; Barrier, J.W.; Lightsey, G.R. 1992" Conversion of Cotton Trash and Other Residues to Liquid Fuel". In Liquid Fuels from Renewable Resources: Proceedings of an Alternative Energy Conference (Cundiff, J.S., ed). American Society of Agricultural Engineers, St. Joseph, Michigan, pp 189-200

[12]. Kenya Standard KS 275.2:2003, Motor Petrol (motor gasoline or motor spirit)-specification, Part 2: Unleaded motor petrol. 